\title{
The Extraterritorial Application of the EU Charter of Fundamental Rights: From Territoriality to Facticity, the Effectiveness Model
}

\section{Select Bibliography}

S Besson, 'The Extraterritoriality of the European Convention on Human Rights: Why Human Rights Depend on Jurisdiction and What Jurisdiction Amounts to' (2012) 25 Leiden Journal of International Law 857.

F Coomans and MT Kamminga (eds), Extraterritorial application of Human Rights Treaties (Antwerp, Intersentia, 2004).

C Costello, 'Courting Access to Asylum in Europe: Recent Supranational Jurisprudence Explored' (2012) 12 Human Rights Law Review 287.

O De Schutter, A Eide, A Khalfan, M Orellana, M Salomon, and I Seiderman, 'Commentary to the Maastricht Principles on Extraterritorial Obligations of States in the Area of Economic, Social and Cultural Rights' (2012) 34 Human Rights Quarterly 1084.

M den Heijer, 'Europe beyond its Borders: Refugee and Human Rights Protection in Extraterritorial Immigration Control', in B Ryan and V Mitsilegas (eds), Extraterritorial Immigration Control (Leiden/Boston, Brill, 2010) 169.

M Gavouneli, Functional Jurisdiction in the Law of the Sea (The Hague, Martinus Nijhoff, 2007).

M Gibney, 'Establishing a Social and International Order for the Realization of Human Rights', in L Minkler (ed), The State of Economic and Social Human Rights: A Global Overview, (Cambridge, CUP, 2013) 251.

M Gondek, The Reach of Human Rights in a Globalizing World (Antwerp, Intersentia, 2009).

A Klug and T Howe, 'The Concept of State Jurisdiction and the Applicability of the Nonrefoulement principle to Extraterritorial Interception Measures', in B Ryan and V Mitsilegas (eds), Extraterritorial Immigration Control: Legal Challenges (The Hague, Martinus Nijhoff, 2010) 69.

M Langford, W Vandehole, M Scheinin and W van Genugten (eds), Global Justice, States' Duties: The Extraterritorial Scope of Economic, Social and Cultural Rights in International Law (Cambridge, CUP, 2013).

AV Lowe, 'Jurisdiction', in M Evans (ed), International Law, 2nd edn (Oxford, OUP, 2006) 335.

M Milanovic, Extraterritorial Application of Human Rights Treaties (Oxford, OUP, 2011).

$S$ Peers, 'Immigration, Asylum and the European Union Charter of Fundamental Rights' (2001) 3 European Journal of Migration and Law 141.

V Moreno-Lax, '(Extraterritorial) Entry Controls and (Extraterritorial) Non-Refoulement in EU Law', in M Maes, M-C Foblets and P De Bruycker (eds), The External Dimensions of EU Asylum and Immigration Policy (Brussels, Bruylant, 2011) 385.

G Noll, 'Seeking Asylum at Embassies: A Right to Entry under International Law?' (2005) 17 International Journal of Refugee Law 542.

M Salomon and I Seiderman, 'Human Rights Norms for a Globalized World: The Maastricht Principles on Extraterritorial Obligations of States in the area of Economic, Social and Cultural Rights' (2012) 3 Global Policy 458. 
M Scheinin, 'Just Another Word? Jurisdiction in the Roadmaps of State Responsibility and Human Rights', in M Langford, W Vandehole, M Scheinin and W van Genugten (eds), Global Justice, States' Duties: The Extraterritorial Scope of Economic, Social and Cultural Rights in International Law (Cambridge, CUP, 2013) 212.

\section{A. Introduction}

59.01 Much commentary on the Charter of Fundamental Rights (EUCFR) ${ }^{1}$ has focused on its potential impact on the internal division of competences between the EU and its Member States. ${ }^{2}$ This chapter is concerned not so much with that internal division, but rather with an issue on which the Charter is apparently silent, namely, its effects on external and extraterritorial action by the EU or its Member States. ${ }^{3}$ Article 51(1) makes clear that the 'provisions of the Charter are addressed to the institutions, bodies, offices and agencies of the Union with due regard for the principle of subsidiarity and to the Member States only when they are implementing Union law.' Accordingly, if EU institutions, bodies, offices and agencies act outside the geographical confines of the EU, the fact of extraterritoriality would seem to be immaterial to the question of the Charter's applicability. The same holds for the Member States, provided they are deemed to be 'implementing' EU law. The Charter's silence on matters of jurisdiction, in particular territorial conceptions of jurisdiction, appears to reflect an assumption that EU fundamental rights obligations simply track all EU activities, as well as Member State action when implementing EU law. This follows from the fact that EU human rights obligations are applicable in all areas governed by EU law or, as the Court puts it, ' $\mathrm{t}$ ] he applicability of European Union law entails applicability of the fundamental rights guaranteed by the Charter.' ${ }^{4}$ The only threshold requirement, therefore, is whether EU law applies to the particular circumstances.

59.02 The initial purpose of this contribution was to argue against the incorporation of any territorial conception of human rights jurisdiction in the Charter. Given the lack of any 'jurisdictional clause' in the Charter, akin to Article 1 of the European Convention of Human Rights (ECHR), ${ }^{5}$ that argument should easily be made out. However, this chapter has a further, more constructive purpose, namely to elucidate why EU human rights law requires no such threshold jurisdictional criterion, unlike some international

\footnotetext{
1 Charter of Fundamental Rights of the European Union, [2010] OJ C83/389.

${ }^{2}$ L Besselink, 'The Member States, the National Constitutions and the Scope of the Charter' (2001) 8 Maastricht Journal 68; R Alonso García, 'The General Provisions of the Charter of Fundamental Rights of the European Union', (2002) 8 European Law Journal 492; F Picod, 'Article II-111 Champ d'Application', in L Burgorgue-Larsen, A Levade and F Picod (eds), Traité établissant une Constitution pour l'Europe, Partie II-La Charte des droits fondamentaux de l'Union Européenne (Brussels, Bruylant, 2002) 643; and P Carozza, 'The Member States', in S Peers and A Ward (eds), The EU Charter of Fundamental Rights: Politics, Law and Policy (Oxford, Hart, 2004) 35. See further, section D below.

3 Throughout, we use the term 'external' to refer to those EU laws and policies that are directed towards third countries. We use the term 'extraterritorial' to capture the instances when those laws and policies are actually applied or have a direct impact on those outside the territory of the Member States of the EU. In this sense, 'extraterritorial' is a subcategory of 'external'.

4 Case C-617/10 Akerberg Fransson (Grand Chamber, Judgment 26 Feburary 2013) [21].

5 European Convention on Human Rights and Fundamental Freedoms, [1950] CETS 5.
} 
human rights treaties. In so doing, we hope this piece makes a distinct, if modest, contribution to the understanding of human rights obligations in external and extraterritorial situations governed by EU law.

At the outset, some terminological clarification is required. The term 'jurisdiction' is used in law in at least two distinct senses. In the classic sense, in public international law (PIL), it is a term that delimits the legal capacity of states to act, that capacity being constrained by the sovereignty of other states. ${ }^{6}$ This concept, which we call 'PIL jurisdiction', has a strong territorial dimension, in that it is assumed that states have the competence to make and enforce law on their own territory. When they seek to act extraterritorially, some specific legal basis must be established for this action. When we come to a non-state entity, like the EU, we tend to use the term 'competence' to capture its capacity to act, as it only has those competences conferred on it by Treaty. ${ }^{7}$ Nonetheless, PIL Jurisdiction is relevant, as the EU often exercises competences that draw on established PIL Jurisdiction of the Member States, ${ }^{8}$ and respect for PIL is a general pre-requisite for EU external action. ${ }^{9}$

However, PIL jurisdiction should not be confused with the particular meaning ascribed to the term 'jurisdiction' in international human rights law (IHRL). In many (although by no means all) IHRL treaties, the term is employed to delimit their scope. ${ }^{10}$ As interpreted by international courts and treaty bodies, 'jurisdiction' in these treaties is distinct from PIL jurisdiction, in that human rights treaty obligations may arise irrespective of whether the state has the power to act. In essence, human rights obligations may result from the fact of acting, typically by exercising some form of control. Human rights treaty obligations can arise in extraterritorial contexts, which are not dependent on the state in question having 'jurisdiction' in the PIL sense. ${ }^{11}$ We call this 'IHRL jurisdiction.'

The Charter is rooted in existing international human rights obligations, from which it takes inspiration, yet is no mere codification. For instance, Article 52(3) clearly envisages situations where EU law may provide more extensive protection than the ECHR.

6 See, for instance, AV Lowe, 'Jurisdiction', in M Evans (ed), International Law, 2nd edn (Oxford, OUP, 2006) 335 .

7 Arts 5(1) and (2) TEU.

8 See fisheries cases in section C.I(c) below and Case C-366/10 Air Transport Association of America and Others $v$ Secretary of State for Energy and Climate Change ('ATA') (Judgment 21 December 2011).

9 See Art 3(5) TEU.

10 For detailed discussions see M Milanovic, Extraterritorial Application of Human Rights Treaties (Oxford, OUP, 2011); M Gondek, The Reach of Human Rights in a Globalizing World (Antwerp, Intersentia, 2009); and F Coomans and MT Kamminga (eds), Extraterritorial Application of Human Rights Treaties (Antwerp, Intersentia, 2004).

11 For a clear exposition of this point, see M den Heijer and R Lawson, 'Extraterritorial Human Rights and the Concept of "Jurisdiction", in M Langford, W Vandenhole, M Scheinin and W van Genugten (eds), Global Justice, State Duties, The Extraterritorial Scope of Economic, Social and Cultural Rights in International Law, (Cambridge, CUP, 2013) 153. Commentary (3) to Principle 8(a) of the Maastricht Principles on Extraterritorial Obligations of States in the Area of Economic, Social and Cultural Rights ('Maastricht Principles' hereinafter) also notes that the concept of jurisdiction in the field of human rights law 'should not be confused with the limits imposed under international law on the ability of a state to exercise prescriptive (or legislative) and enforcement jurisdiction'. See O De Schutter, A Eide, A Khalfan, M Orellana, M Salomon and I Seiderman, 'Commentary to the Maastricht Principles on Extraterritorial Obligations of States in the Area of Economic, Social and Cultural Rights' (2012) 34 Human Rights Quarterly 1084, 1102. The text of the Principles is available at, www.fian.org/fileadmin/media/publications/2012.02.29_Maastricht_Principles_on_ Extraterritorial_Obligations.pdf. 
According to the Explanations to Article 52,12 the autonomy of EU law should be upheld. ${ }^{13}$ The Explanations to Article 53 specify, in turn, that that article is intended to maintain the level of protection currently afforded within their respective scope by Union law, national law and international law'. Therefore, the need to incorporate all concepts from IHRL, especially the notion of IHRL jurisdiction, is not straightforward.

59.06 International human rights treaties contain particular compromises and features that reflect the resilience, or at least the residue, of the statist paradigm of international legality, which are absent from the wording and scheme of the Charter. Constructive engagement between IHRL and EU law can be fruitful, provided the EU is mindful of its distinct constitutional frame. Fundamental rights are 'embedded' within the EU legal order; in the words of Eeckhout, they are "fully integrated with the "remainder" of EU law,', in a manner that means that they can transcend some of the limitative features of IHRL. Our central claim is precisely that, in the constitutional context of the EU, there is a pervasive requirement for the Union and its Member States to comply with fundamental rights in all spheres governed by EU law. ${ }^{15}$ There is no analogue of IHRL jurisdiction acting as a threshold criterion determining the applicability of the Charter.

59.07 In section $\mathrm{B}$, we set out the range of EU Treaty provisions that support this allembracing applicability of EU human rights norms, including Article 51 of the Charter. ${ }^{16}$ Section C.I then examines the relevance of PIL jurisdiction to the question of the scope of EU competences, using illustrations from diverse fields, namely the Internal Market, Common Fisheries Policy, commercial sanctions, and climate change. These examples also serve to illustrate the range of scenarios in which EU law may apply extraterritorially, sometimes in keeping with PIL jurisdictional orthodoxy, at other times seemingly straining against its confines in controversial ways. Section C.II sketches developments in relation to IHRL jurisdiction, including recent attempts to conceptualise the extraterritorial scope of economic and social rights in the Maastricht Principles. ${ }^{17}$ Ultimately though, we argue that IHRL jurisdiction has no place in EU law. Rather, we focus on the EU notion of fundamental rights applicability under autonomous requirements of the EU legal system. We illustrate this by reference to EU extraterritorial actions in the Area of Freedom, Security and Justice, and Common Foreign and Security Policy. In section D, we discuss relevant CJEU case law showing that once EU law is applicable to a given scenario, the Charter follows, including in situations where the applicability of IHRL would be contested on jurisdictional grounds. Section E closes the chapter, offering a series of concluding remarks.

\footnotetext{
12 See examples of Charter provisions extending wider protection than ECHR rights in para 2 of the Explanation to Article 52-Scope and interpretation of rights and principles. See Explanations relating to the Charter of Fundamental Rights, [2007] OJ C303/17.

13 For a substantiation of this autonomy in relation to Art 47 of the Charter, see AG Cruz Villalón, Opinion of 1 March 2011, Case C-69/10 Samba Diouf [2011] ECR I-7151 [39].

14 P Eeckhout, 'Human Rights and the Autonomy of EU Law, Pluralism or Integration?' (2013) Current Legal Problems 1, 10.

15 Joined Cases C-402/04 P and C-415/05 P Kadi I [2008] ECR I-6351 and Joined Cases C-584/10 P, C-593/10 P and C-595/10 P Kadi II (Grand Chamber, Judgment 18 July 2013).

16 See the commentary on Art 51 by Angela Ward in this volume.

17 See in particular the Maastricht Principles and Commentary, above n 9.
} 


\section{B. Relevant Provisions: The Treaty and the Charter}

The Charter does not contain a jurisdictional clause akin to Article 1 ECHR, delimiting its scope of application. In contrast, the following general provisions of the Treaty on the European Union (TEU $)^{18}$ illustrate the general scope of EU fundamental rights:

\section{Article 2 TEU}

The Union is founded on the values of respect for human dignity, freedom, democracy, equality, the rule of law and respect for human rights, including the rights of persons belonging to minorities. These values are common to the Member States in a society in which pluralism, nondiscrimination, tolerance, justice, solidarity and equality between women and men prevail.

\section{Article 6 TEU}

1. The Union recognises the rights, freedoms and principles set out in the Charter of Fundamental Rights of the European Union of 7 December 2000, as adapted at Strasbourg, on 12 December 2007, which shall have the same legal value as the Treaties.

The provisions of the Charter shall not extend in any way the competences of the Union as defined in the Treaties.

The rights, freedoms and principles in the Charter shall be interpreted in accordance with the general provisions in Title VII of the Charter governing its interpretation and application and with due regard to the explanations referred to in the Charter, that set out the sources of those provisions.

2. The Union shall accede to the European Convention for the Protection of Human Rights and Fundamental Freedoms. Such accession shall not affect the Union's competences as defined in the Treaties.

3. Fundamental rights, as guaranteed by the European Convention for the Protection of Human Rights and Fundamental Freedoms and as they result from the constitutional traditions common to the Member States, shall constitute general principles of the Union's law.

\section{Article 21 TEU}

1. The Union's action on the international scene shall be guided by the principles which have inspired its own creation, development and enlargement, and which it seeks to advance in the wider world: democracy, the rule of law, the universality and indivisibility of human rights and fundamental freedoms, respect for human dignity, the principles of equality and solidarity, and respect for the principles of the United Nations Charter and international law.

The Union shall seek to develop relations and build partnerships with third countries, and international, regional or global organisations which share the principles referred to in the first subparagraph. It shall promote multilateral solutions to common problems, in particular in the framework of the United Nations.

These provisions demonstrate the foundational and pervasive character of human rights in EU law. They permeate the EU legal order in multiple forms: as primary law

18 Treaty on European Union, [2010] OJ C83/13. 
(codified in the Charter), as general principles (extracted from IHRL and common constitutional traditions of the Member States), and as minimum standards for action on the international scene (in accordance with international law). No reference is made, however, to territory or jurisdiction in any of these provisions.

\section{Article 51 EUCFR}

1. The provisions of this Charter are addressed to the institutions, bodies, offices and agencies of the Union with due regard for the principle of subsidiarity and to the Member States only when they are implementing Union law. They shall therefore respect the rights, observe the principles and promote the application thereof in accordance with their respective powers and respecting the limits of the powers of the Union as conferred on it in the Treaties.

2. The Charter does not extend the field of application of Union law beyond the powers of the Union or establish any new power or task for the Union, or modify powers and tasks as defined in the Treaties.

59.10 Article 51(1) makes clear that the 'provisions of the Charter are addressed to the institutions, bodies, offices and agencies of the Union with due regard for the principle of subsidiarity'. Accordingly, if those institutions, bodies, offices and agencies act outside the territory of the EU Member States, the extraterritoriality of the action is immaterial to the question of the Charter's applicability. Admittedly, Article 51(2) emphasises that the Charter does not increase the EU's powers or alter the field of application of Union law, so the EU's obligation to respect, protect and promote fundamental rights ${ }^{19}$ only applies to the extent that competences exist in a given field. ${ }^{20}$ At the same time, the EU has extensive external competences, and does often act externally. The Charter seems to reflect a general understanding that EU fundamental rights obligations simply track EU activities, whether they take place within or without territorial boundaries. It does not create any new obligation, but provides a framework of evaluation to appraise the compatibility of the relevant action/omission with fundamental rights.

59.11 This is not to say that PIL jurisdiction plays no role in EU law, as the next section demonstrates. Nonetheless, in light of the wording, object and purpose of the above provisions and on account of developments in the case law of the Court of Justice, we maintain that IHRL jurisdiction is not a threshold requirement for the applicability of EU human rights law.

19 The Office of the UN High Commissioner for Human Rights states on its website that, 'By becoming parties to international treaties, States assume obligations and duties under international law to respect, to protect and to fulfil human rights'; retrieved from www.ohchr.org/en/professionalinterest/Pages/ InternationalLaw.aspx.

20 See Opinion of AG Sharpston in Case C-34/09 Zambrano (30 September 2010), to the effect that the scope of EU fundamental rights, to the extent that they apply to the Member States, could expand to apply not only where there are EU norms being implemented or derogated from, but also merely where EU competences exist. See para 165 et seq of the Opinion. 


\section{The Place of 'Jurisdiction' in the EU Legal Order}

\section{I. 'PIL Jurisdiction' and EU Law}

PIL jurisdiction, as defined above, is closely related to notions of territorial exclusivity and state sovereignty. Within its territorial domain, a state is considered to possess exclusive power for the enactment and enforcement of law. For intervention abroad, PIL defines a limited number of bases for a state to extend its jurisdiction extraterritorially. These comprise nationality, flag, passive personality, effect, protection, diplomatic and consular relations, and universality. ${ }^{21}$ Outside these customary sources for extraterritorial jurisdiction, states need the consent, invitation or acquiescence of the territorial sovereign for action beyond their geographical confines. ${ }^{22}$ Evidently, the EU is not a state, and these hallmarks of statehood are not features of the organisation. Nonetheless, the EU as a subject of international law is bound by general PIL norms, ${ }^{23}$ so PIL jurisdiction both informs and constrains the exercise of EU competences. ${ }^{24}$

The EU and the Territory of the Member States

EU law traditionally does not refer to the EU as having, or being defined by, territory. The Treaty is replete with references to Member State territory, ${ }^{25}$ but contains only one reference to the 'territory of the Union' ${ }^{26}$ The Court occasionally speaks of the territory of the Union, ${ }^{27}$ but most of the time territory is a statist conception and rests at the Member State level. Even in those fields of activity where EU action has a spatial, geographical dimension, it uses concepts other than territory. For instance, the Internal Market is an 'area without internal frontiers in which the free movement of goods, persons, services, and capital is ensured'. ${ }^{28}$ The term reappears to denote the '[a]rea of Freedom, Security and Justice. ${ }^{29}$ In these contexts, as is discussed below, references to territorial jurisdiction relate to that of the Member States.

21 The enumeration is taken from Bankovic v Belgium App no 52207/99 (ECtHR [GC], Admissibility 12 December 2001) [59].

22 See Al-Skeini v United Kingdom App no 55721/07 (ECtHR [GC], 7 July 2011) [153].

23 See generally, MP Scharf, The Law of International Organisations, 2nd edn (Durham NC, Carolina Academic Press, 2007); and C Alhborn, 'The Rules of International Organizations and the Law of International Responsibility' (2011) 8 International Organisations Law Review 397.

${ }^{24}$ See Art 3(5) TEU.

25 See, for instance, Art 42(7) TEU (on CSDP); Art 55(2) TEU (on the languages in which the Treaty may be translated); Art 79(3) and (5) TFEU (on volumes of admission and the readmission of migrants); Art 88(3) TFEU (on EUROPOL operational action); Art 222 TFEU (on solidarity in the event of a terrorist attack or natural or man-made disaster).

26 Art 153(g) TFEU refers to setting 'conditions of employment for third-country nationals legally residing in Union territory' (emphasis added).

27 See, for instance, Case C-34/09 Zambrano [2011] ECR I-1177 [44]; Case C-434/09 McCarthy [2011] ECR I-3375 [50]; and Case C-256/11 Dereci [2011] ECR I-11315 [65], [66], [68].

28 Art 26(2) TFEU (emphasis added).

29 Art 67(1) TFEU (emphasis added). 
59.14 Article 52(1) TEU may appear to set a territorial limitation to the law of the Union. The clause provides that the EU Treaties 'shall apply to the [EU Member States]'. Paragraph 2 refers, in turn, to Article 355 of the Treaty on the Functioning of the European Union (TFEU), ${ }^{31}$ which makes provision for the 'special arrangements' applicable to overseas countries and territories having special relations with the Member States to be taken into account. The clause, therefore, is reminiscent of the so-called territorial clauses found in some human rights instruments, such as Article 40 of the 1951 Refugee Convention ${ }^{32}$ or Article 56 ECHR.

59.15 However, the ultimate function of Articles 52 TEU and 355 TFEU is not to demarcate the field of application of EU law, but to enumerate the High Contracting Parties that are bound by it. Like Article 51 for the purposes of the Charter, Articles 52 TEU and 355 TFEU list the addressees of the obligations flowing from the Union Treaties. Even those aspects of EU policy with internal focus are not tightly territorially constrained, as is evident in the discussion of the external aspects of the Internal Market and other policies below. In these fields-irrespective of the nature of the competence at play (shared, in the case of the Internal Market; partly exclusive, in that of Common Fisheries), ${ }^{33}$ once the European Union is found competent to act-a conclusion which is informed by PIL jurisdiction, EU law may apply extraterritorially.

\section{(a) The Internal Market}

59.16 While the Internal Market seeks to ensure free movement of products and factors of production across the territory of the Member States, ${ }^{34}$ Treaty freedoms are not read as applying solely within that territory. Internal Market norms have been construed broadly, conferring on them an external dimension informed by PIL jurisdiction. To delimit the scope of the relevant provisions, the CJEU has used the notion of a 'cross-border' dimension, ${ }^{35}$ a potential 'restriction' on the exercise of the Treaty freedom concerned, ${ }^{36}$ or a significant 'connection' to the Union to determine the applicability of EU law. ${ }^{37}$

${ }^{30}$ Listed as the Kingdom of Belgium, the Republic of Bulgaria, the Czech Republic, the Kingdom of Denmark, the Federal Republic of Germany, the Republic of Estonia, Ireland, the Hellenic Republic, the Kingdom of Spain, the French Republic, the Italian Republic, the Republic of Cyprus, the Republic of Latvia, the Republic of Lithuania, the Grand Duchy of Luxembourg, the Republic of Hungary, the Republic of Malta, the Kingdom of the Netherlands, the Republic of Austria, the Republic of Poland, the Portuguese Republic, Romania, the Republic of Slovenia, the Slovak Republic, the Republic of Finland, the Kingdom of Sweden and the United Kingdom of Great Britain and Northern Ireland.

31 Treaty on the Functioning of the European Union, [2010] OJ C83/47.

32 Convention relating to the Status of Refugees, [1951] 189 UNTS 150.

33 Arts 3(d) and 4(2)(a) TFEU.

34 Art 20(2)(a) and 21(1) TFEU speak of EU 'citizens' right to 'move and reside freely within the territory of the Member States', a formula repeated in Art 45 TFEU on free movement of workers and Art 49 on the right of establishment. See, generally, on the 'four freedoms', Art 26(2) TFEU.

35 See, as one recent example, Case C-172/11 Erny (Judgment 28 June 2012), on tax on wages of EU workers.

36 See, for instance, the line of name cases decided by the Court, where it considered that differing regulations across EU jurisdictions could cause divergences in how the same person is named under different systems, thereby creating problems to the effective exercise of free movement rights of the persons concerned: Case C-148/02 Garcia Avelló [2003] ECR I-11613; Case C-353/06 Grunkin and Paul [2008] ECR I-7639; Case C-208/09 Sayn-Wittgenstein [2010] ECR I-13693; and Case C-391/09 Runevič-Vardyn (Judgment 12 May 2011).

37 See, in particular, Case C-138/02 Collins [2004] ECR I-2703 [29]. For a probing analysis of this concept, see C O'Brien, 'Real links, abstract rights and false alarms, the relationship between the ECJ's "real link" case law and national solidarity' (2008) 33 European Law Review 643. 
In Union Cycliste Internationale, ${ }^{38}$ the EU norm of non-discrimination on grounds of nationality was applied to legal relationships established under the auspices of an international sporting federation. The Court concluded that the principle extended to 'all legal relationships in so far as these relationships, by reason either of the place where they are entered into or of the place where they take effect, can be located within the territory of the Community. ${ }^{39}$ Similarly in Prodest, ${ }^{40}$ a case concerning a Belgian national employed by a French company but temporarily posted to Nigeria, the CJEU held that he was still within the scope of the Treaty provisions 'as long as the employment relationship retains a sufficiently close link to [the territory of the Community]." ${ }^{41}$ Then, in Lopes da Veiga ${ }^{42}$ the Court pointed out that such a link could even be identified in the case of a Portuguese national permanently employed on vessels flying the Dutch flag sailing on the high seas. The Court relied on the vessel's flag, the seaman's nationality, and the fact that the employment relationship was subject to Dutch law and the worker paid his taxes in the Netherlands to establish the relevant link. ${ }^{43}$ No reference was made in any of these cases to jurisdiction or competence as such and no territorial limitation was deduced from Articles 52 TEU and 355 TFEU.

In Boukhalfa, Germany argued against the applicability of Internal Market norms to a case concerning a Belgian national employed as local staff of its Embassy in Algiers, on a contract subject to Algerian law. The Court of Justice rejected the argument put forward by the German government on the effect of Articles 52 TEU and 355 TFEU and, building on Prodest, it established that the prohibition of nationality discrimination was applicable. ${ }^{44}$ Arguably, PIL jurisdiction based on both nationality and the special jurisdictional regime on diplomatic and consular premises influenced the finding of a meaningful link to EU law. In addition, the Court explicitly affirmed that ' $\mathrm{t}$ ] he geographical application of the Treaty [as] defined in Article [52 EU and Article 355 TFEU] ... does not, however, preclude Community rules from having effects outside the territory of the Community. ${ }^{35}$

These cases illustrate that, even in relation to the Internal Market, EU law may apply extraterritorially. The circumstances when it does depend on various factors, not decisively related to territory. The cases also show that once EU law is found to apply, so too fundamental guarantees, as the principle of non-discrimination on grounds of nationality.

\section{(b) Common Fisheries Policy}

In its common policy on fisheries, the EU has expressly drawn on PIL jurisdiction to shape its own competence, as in the external arena EU powers may well be constrained by other states' territorial sovereignty. In this sense, PIL jurisdiction is relevant to delimit

\footnotetext{
38 Case 36/74 Union Cycliste Internationale [1974] ECR 1405.

39 Ibid [28] (emphasis added).

40 Case 237/83 Prodest [1984] ECR 3153.

41 Ibid [6], [10] (emphasis added).

42 Case 9/88 Mario Lopes da Veiga [1989] ECR 2989.

43 Ibid [16], [19].

44 Case C-214/94 Ingrid Boukhalfa v Federal Republic of Germany [1996] ECR I-2253 [22].

45 Ibid [14]-[15].
} 
the EU's capacity to act. Nonetheless, it is striking that, as the examples below show, even when it comes to delimiting capacity to act, territorial demarcations are not the decisive criterion in the EU law framework.

59.21 The international law of the sea approach to 'functional jurisdiction' 46 has informed EU law. ${ }^{47}$ For instance, in Kramer, the CJEU held that EU rules on the conservation of the biological resources of the sea extended not only to the territorial waters of the Member States, but also to the high seas, 'in so far as the Member States have similar authority under public international law. ${ }^{48}$ Accordingly, in Commission v Spain, the Court held that EU measures to control fishing by EU vessels applied to catches made on the high seas, 'outside the Community fishing zone'. ${ }^{49}$ Mondiet confirmed that 'with regard to the high seas, the Community has the same rule-making authority in matters within its jurisdiction as that conferred under international law on the state whose flag the vessel is flying or in which it is registered..$^{50}$ As a result, in Commission $v U K$, the Habitats Directive ${ }^{51}$ was found 'applicable beyond the Member States' territorial waters'. The UK had limited transposition into national law to just national territory and territorial waters, considering that within their exclusive economic zone Member States did not have an obligation to comply with EU law. The Court rejected the argument and ruled instead that, in so far as 'the United Kingdom exercises sovereign rights in its exclusive economic zone ... [i]t follows that the directive must be implemented in that exclusive economic zone.. ${ }^{52}$

\section{(c) Commercial Sanctions and Climate Change-Effectiveness and PIL Jurisdiction}

59.22 In both the Internal Market and fisheries contexts, the scope of EU law draws faithfully on PIL jurisdictional concepts. By contrast, in the two final illustrations, commercial sanctions and climate change, we see EU extraterritorial legislation and enforcement action developing a strong effectiveness dimension. Whilst the EU is bound by PIL, in these cases we witness developments sitting uneasily with PIL orthodoxy-if not dismissing the relevant standards.

59.23 Ebony Maritime illustrates that EU sanctions may apply extraterritorially, even when the legislative basis for such scope is unclear. ${ }^{53}$ In spite of the wording of a territorial clause contained in the relevant Regulation, ${ }^{54}$ giving effect to a UN Resolution prohibiting

46 On this conception of jurisdiction see, generally, M Gavouneli, Functional Jurisdiction in the Law of the Sea (The Hague, Martinus Nijhoff, 2007). Refer also to BD Smith, State Responsibility and the Marine Environment, The Rules of Decision (Oxford, Clarendon Press, 1988).

47 For commentary, analysis and further references on this point, see S Boelaert-Suominen, 'The European Community, the European Court of Justice and the Law of the Sea' (2008) 23 International Journal of Marine and Coastal Law 643.

48 Joined Cases 3, 4 and 6/76 Kramer [1976] ECR 1279 [30]-[33]. See also Case 167/73 Commission v France [1974] ECR 359.

49 Case C-258/89 Commission v Spain [1991] ECR I-3977 [18].

50 Case C-405/92 Mondiet [1993] ECR I-6133 [12] (emphasis added). Further confirmed in Case C-25/94 Commission v Council (FAO) [1996] ECR I-1469 [44].

${ }^{51}$ Directive 92/43/EEC on the conservation of natural habitats and of wild fauna and flora [1992] OJ L206/7.

52 Case C-6/04 Commission v UK [2005] ECR I-9017 [117].

53 Ebony Maritime [1997] ECR I-1111 [17] et seq.

54 Council Regulation (EEC) 990/93 concerning trade between the European Economic Community and the Federal Republic of Yugoslavia (Serbia and Montenegro) [1993] OJ L102/14. Art 11 explicitly limits its applicability to 'the territory of the Community, including its air space and ... any aircraft or vessel under 
entry into Yugoslavian waters for commercial maritime traffic, ${ }^{55}$ the Luxembourg Court considered that the sanctions contemplated therein extended to the high seas. ${ }^{56}$ What is more, the Court established that coercive measures, such as detention, seizure and confiscation of vessels and their cargos, applied 'not only to actual entries, but also to attempted entries into those territorial waters by vessels in international waters., ${ }^{57}$ Neither the principle of legality and narrow interpretation of punitive provisions, ${ }^{58}$ nor the principle of freedom of navigation on the high seas ${ }^{59}$ deterred the Court from concluding that ' $[a]$ ny other interpretation would risk rendering the prohibition ineffective. ${ }^{60}$ Eventually, the principle of effectiveness of EU law played a crucial part in the purposive interpretation of the Regulation, with little consideration being paid to PIL notions of jurisdiction, despite explicit references therein.

Concerning climate change, the EU has legislated in an expansive way, applying its emissions trading legislation to all emissions from flights that originate outside the EU, but land there and vice versa. ${ }^{61}$ Unsurprisingly, this exercise of competence has met with opposition from states which see it as an intrusion into their territorial sovereignty, in particular the United States. US airlines challenged the EU Regulation before the CJEU, but the Court took an expansive notion of the EU's competence, ${ }^{62}$ holding that departure from or arrival at an EU airport was a sufficiently close jurisdictional nexus. Commentators have been divided in their reactions, from those who see it as creating space for regional environmental leadership, given global deficits, ${ }^{63}$ to others who view the ruling as biased and distortive of PIL. ${ }^{64}$ For our purposes, the case illustrates further that the CJEU is developing a complex case law informed by and arguably expanding on PIL jurisdiction, whereby unswerving adherence to traditional precepts is open to question.

The overall conclusion that can be reached from this survey is that EU Courts and EU law have drawn inspiration from PIL jurisdiction to establish the relevance and applicability of EU norms in extraterritorial situations. However, these notions have not been decisive, with Luxembourg judges extending the scope of EU law beyond the realm of PIL considerations, taking account of the nature and repercussion of European integration. The focus has rather been on particular effects and result, with the principle of effectiveness of EU rights and obligations assuming a significant role.

the jurisdiction of a Member States, and ... any person elsewhere who is a national of a Member State and anybody elsewhere which is incorporated or constituted under the law of a Member State'.

55 UNSC Resolution 820 (1993), available at, http://daccess-dds-ny.un.org/doc/UNDOC/GEN/N93/222/97/ IMG/N9322297.pdf?OpenElement.

56 Ebony Maritime (n 53) [17] et seq.

57 Ibid [25] (emphasis added).

58 See Art 49 EUCFR, Art 15 ICCPR and Art 7 ECHR.

59 Refer to Art 87(1)(a) UN Convention on the Law of the Sea, [1982] 1833 UNTS 3.

60 Ebony Maritime (n 53) [25].

61 Directive 2008/101/EC amending Directive 2003/87/EC so as to include aviation activities in the scheme for greenhouse gas emission allowance trading within the Community [2009] OJ L8/3.

62 ATA (n 8).

63 See S Bogojević, 'Legalising Environmental Leadership, A Comment on the CJEU's Ruling in C-366/10 on the Inclusion of Aviation in the EU Emissions Trading Scheme' (2012) 24 Journal of Environmental Law 345; and C Voigt, 'Up in the Air-Aviation, the EU Emissions Trading Scheme and the Question of Jurisdiction' (2012) 13 Cambridge Yearbook of European Legal Studies 475.

${ }^{64}$ B Havel and J Mulligan 'The Triumph of Politics, Reflections on the Judgment of the Court of Justice of the European Union Validating the Inclusion of Non-EU Airlines in the Emissions Trading Scheme' (2012) 37 Air and Space Law 3. 


\section{II. 'IHRL Jurisdiction' and EU Law}

59.26 IHRL jurisdiction refers to a specific feature of most international human rights treaties, namely that they either contain a specific clause delimiting their application to acts within the State Parties' 'jurisdiction' or are deemed to be subject to such a limitation. There is some scholarly debate as to the utility of the concept. Some, such as Besson, see IHRL jurisdiction as basic to the understanding of the relationship between human rights holders and duty bearers. ${ }^{65}$ In contrast, Scheinin argues that 'jurisdiction' does not add anything to the key aspects of admissibility and State responsibility in IHRL and should be considered an empty notion. ${ }^{66}$ Another view questions the appropriateness of attempting a general synthesis of the notion of IHRL jurisdiction. ${ }^{67}$

59.27 This chapter treats IHRL jurisdiction as a distinct feature of international treaties in this field, and one whose logic dictates that it is ill-fitting in the EU context. Nonetheless, for illustrative purposes, this section provides an overview of key instruments' approaches to jurisdiction and introduces a final sub-section on the EU's approach to the extraterritorial application of human rights.

\section{UDHR}

59.28 The Universal Declaration of Human Rights (UDHR) ${ }^{68}$ has no jurisdiction clause, which should come as no surprise given its declaratory nature. Moreover, its conception of human rights as 'universal' includes a duty to cooperate to realise human rights globally. To that end, Article 28 provides that '[e]veryone is entitled to a social and international order in which the rights and freedoms in this Declaration can be fully realized.' States have a duty to cooperate in establishing such an order. ${ }^{69}$

\section{ICCPR}

59.29 The International Covenant on Civil and Political Rights (ICCPR) ${ }^{70}$ states that the duties therein apply to 'all individuals within [the state's] territory and subject to its jurisdiction' in Article 2(1). Although the text of the ICCPR refers to both 'territory' and

65 S Besson, 'The Extraterritoriality of the European Convention on Human Rights, Why Human Rights Depend on Jurisdiction and What Jurisdiction Amounts to' (2012) 25 Leiden Journal of International Law 857. She argues that 'jurisdiction qua normative relationship between subjects and authorities actually captures the core of what human rights are about qua normative relationships between right-holders and institutions as duty-bearers.'

${ }^{66}$ M Scheinin, 'Just Another Word? Jurisdiction in the Roadmaps of State Responsibility and Human Rights', in M Langford, W Vandehole, M Scheinin and W van Genugten (eds), Global Justice, States Duties, The Extraterritorial Scope of Economic, Social and Cultural Rights in International Law (Cambridge, CUP, 2013) 212.

${ }^{67}$ For a critique of the use of the notion of 'jurisdiction' in the Mastricht Principles, see N Van Der Have, 'The Maastricht Principles on Extraterritorial Obligations in the area of ESC rights-Comments to a Commentary' (2013), available at www.sharesproject.nl/the-maastricht-principles-on-extraterritorialobligations-in-the-area-of-esc-rights-comments-to-a-commentary/.

68 Universal Declaration of Human Rights, UN General Assembly Res 217A, UN Doc A/810 at 71 (1948).

69 See, for example, 1986 Declaration on the Right to Development, UN General Assembly, A/RES/41/128, 4 December 1986. See generally, M Gibney, 'Establishing a Social and International Order for the Realization of Human Rights', in L Minkler (ed), The State of Economic and Social Human Rights, A Global Overview (Cambridge, CUP, 2013) 251.

70 International Covenant on Civil and Political Rights, [1966] 999 UNTS 171. 
'jurisdiction, ${ }^{71}$ the Human Rights Committee, displaying some creativity, interprets it as applying 'to anyone within the power or effective control of that State party, even if not situated within the territory of the State party. ${ }^{72}$ This interpretation of the jurisdictional clause in Article 2(1) ICCPR was originally advocated by Thomas Buergenthal. ${ }^{73}$ The Human Rights Committee employs a criterion of effective control over persons to establish jurisdiction, which appears to be set at a lower threshold than that employed by the ECtHR—at least in its pre-Al-Skeini case law. ${ }^{74}$

\section{ICESCR}

The International Covenant on Economic, Social and Cultural Rights (ICESCR) ${ }^{75}$ does not contain a jurisdictional clause, although the Optional Protocol thereto only allows complaints to be submitted by those within the respondent state's jurisdiction. ${ }^{76}$ The recent authoritative attempt to delineate extraterritorial obligations as regards economic, cultural and social rights in the Maastricht Principles employs the concept of 'jurisdiction', but defined capaciously. ${ }^{77}$ The principles naturally focus on economic and social rights, but are informed by general developments in international human rights law, reflecting the indivisibility of human rights. For instance, Principle 2 provides that:

All States have obligations to respect, protect and fulfill human rights, including civil, cultural, economic, political and social rights, both within their territories and extraterritorially.

Principle 9 further specifies that:

A State has obligations to respect, protect and fulfill economic, social and cultural rights in any of the following:

a) situations over which it exercises authority or effective control, whether or not such control is exercised in accordance with international law;

b) situations over which State acts or omissions bring about foreseeable effects on the enjoyment of economic, social and cultural rights, whether within or outside its territory;

c) situations in which the State, acting separately or jointly, whether through its executive, legislative or judicial branches, is in a position to exercise decisive influence or to take

71 To read this phrase cumulatively would exclude extraterritorial effects.

72 Human Rights Committee, General Comment No 31, The Nature of the General Legal Obligation Imposed on States Parties to the Covenant, 12 May 2004, UN Doc HRI/GEN/1/Rev 7 [195]. The ICJ subsequently confirmed this view in its Advisory Opinion on the Legal Consequences of the Construction of a Wall in the Occupied Palestinian Territory, Advisory Opinion, [2004] ICJ Reports 136, 179. Cf Noll, 'Seeking Asylum at Embassies, A Right to Entry under International Law?' (2005) 17 International Journal of Refugee Law 542, 557, for a sceptical assessment of the Human Rights Committee's attempt 'to rework the cumulative criteria' in Art 2(1) ICCPR.

73 T Buergenthal, 'To Respect and to Ensure, State Obligations and Permissible Derogations', in L Henkin (ed), The International Bill of Rights, The Covenant on Civil and Political Rights (New York, Columbia University Press, 1981) 72-91. See further, T Meron, 'Extraterritoriality of Human Rights Treaties' (1995) 89 American Journal of International Law 78.

74 See A Klug and T Howe, 'The Concept of State Jurisdiction and the Applicability of the Non-refoulement principle to Extraterritorial Interception Measures', in B Ryan and V Mitsilegas (eds), Extraterritorial Immigration Control, Legal Challenges (The Hague, Martinus Nijhoff, 2010) 69.

75 International Covenant on Economic, Social and Cultural Rights, [1966] 993 UNTS 3.

76 Optional Protocol to the International Covenant on Economic, Social and Cultural Rights, UN General Assembly Res 63/117 (2008).

77 Maastricht Principles, above n 11. 
measures to realize economic, social, and cultural rights extraterritorially, in accordance with international law.

59.32 Principle 9(a) broadly reflects the approach that has been developed in the context of international adjudication on civil and political rights, including under the ECHR post Al-Skeini. ${ }^{78}$ Under Principle 9(b), the Principles draw on dicta of the ECtHR, to the effect that jurisdiction 'may extend to acts of its authorities which produce effects outside its own territory. ${ }^{79}$ The Court has also noted that '[a] State's responsibility may ... be engaged on account of acts which have sufficiently proximate repercussions on rights guaranteed by the Convention, even if those repercussions occur outside its jurisdiction. ${ }^{80}$ Principle 9(c) introduces a broader notion of jurisdiction, where states exercise 'decisive influence' or can contribute to the realisation of such rights extraterritorially, allowing for the integration of duties of international cooperation under the notion of human rights jurisdiction. ${ }^{81}$

59.33 The duty of international assistance and cooperation is also strongly expressed in Article 2(1) ICESCR. Each state 'undertakes to take steps, individually and through international assistance and co-operation, especially economic and technical, to the maximum of its available resources with a view to achieving progressively the full realization of the rights recognized in the Covenant. ${ }^{82}$

\section{CAT}

59.34 Article 3 of the Convention against Torture and Other Cruel, Inhuman or Degrading Treatment or Punishment (CAT $)^{83}$ contains no geographical limitation, leading to a broad construction of its scope of application. ${ }^{84}$ The CAT Committee has confirmed that jurisdiction may arise de jure, ie where the state is entitled to act under traditional precepts of public international law, or de facto, where there is control over persons or territory. ${ }^{85}$ In the Marine I case, the Committee held that Spain maintained such control over migrants rescued at sea and brought to Mauritania and detained there. ${ }^{86}$ The finding has been confirmed in the Sonko case, where the Spanish Guardia Civil had rescued migrants at sea, taking them on board a Spanish vessel. They (in disputed factual circumstances) threw the migrants into Moroccan territorial waters. These actions, which led to the applicant's death by drowning, were held to fall within Spanish jurisdiction. The officers were deemed responsible for the swimmers' safety, because they exercised control over the persons in the vessel. ${ }^{87}$

\footnotetext{
78 Commentary to the Maastricht Principles, above n 11, fn 62 p 1108, referring to Al-Skeini v United Kingdom (n 22) [138]-[139].

79 Al-Skeini v United Kingdom (n 22) [133].

${ }^{80}$ Ilascu and Others $v$ Moldova and Russia App no 48787/99 (ECtHR [GC], 8 July 2004) [317].

81 Commentary to the Maastricht Principles, above n 11, 1109.

82 See also, Art 11(1) ICESCR on the adequate standard of living.

${ }^{83}$ Convention against Torture and Other Cruel, Inhuman or Degrading Treatment or Punishment, UN General Assembly Res 39/46, Annex, 39 UN GAOR supp (No 51) at 197, UN Doc A/39/51 (1984).

${ }^{84}$ G Goodwin-Gill and J McAdam, The Refugee in International Law, 3rd edn (Oxford, OUP, 2007) 248.

85 Committee Against Torture, General Comment No 2, 23 November 2007, CAT/C/GC/2/CRP.1/Rev.4 [16].

86 Committee Against Torture, JHA v Spain, Communication No 323/2007, 10 November 2008 [8.2]. For analysis, see K Wouters and M den Heijer, 'The Marine I Case, A Comment', (2010) 22 International Journal of Refugee Law 1.

87 Committee Against Torture, Sonko v Spain, Communication No 368/2008, 25 November 2011.
} 


\section{CEDAW}

Like the ICESCR, the Convention to Eliminate All Forms of Discrimination against Women $(\mathrm{CEDAW})^{88}$ contains no express jurisdictional clause, although the Optional Protocol only allows complaints to be submitted by those with the relevant state's jurisdiction. ${ }^{89}$ The CEDAW Committee has confirmed that CEDAW applies to the actions of a state outside its territory, establishing that 'States parties are responsible for all their actions affecting human rights, regardless of whether the affected persons are in their territory. ${ }^{\prime 90}$

\section{CERD}

The Convention on the Elimination of All Forms of Racial Discrimination (CERD) ${ }^{91}$ does not contain a general jurisdictional clause either, but key articles use the term 'jurisdiction. ${ }^{92}$ In particular, Article 6 CERD refers to State Parties' duty to ensure 'effective protection and remedies' to 'everyone within their jurisdiction.' In addition, Article 14, which provides the option to permit the CERD Committee to hear individual complaints, refers to 'communications from individuals or groups of individuals within its jurisdiction claiming to be victims of a violation by that State Party of any of the rights set forth in this Convention.'

In its decision on Provisional Measures in Application of the International Convention on the Elimination of all Forms of Racial Discrimination (Georgia $v$ Russian Federation), the International Court of Justice noted that CERD had no territorial restriction of either a general or specific nature. Accordingly, the pertinent CERD provisions applied when the State Party acted beyond its territory. The ICJ called on both Russia and Georgia to 'do all in their power to ensure that public authorities and public institutions under their control or influence do not engage in acts of racial discrimination against persons, groups of persons or institutions. ${ }^{93}$

\section{CRC}

The Convention on the Rights of the Child (CRC) ${ }^{94}$ applies to 'each child within [the state's] jurisdiction' ${ }^{95}$ The Committee on the Rights of the Child recently explained that:

Under the Convention, States have the obligation to respect and ensure children's rights within their jurisdiction. The Convention does not limit a State's jurisdiction to 'territory'. In

\footnotetext{
88 Convention on the Elimination of All Forms of Discrimination against Women UN General Assembly Res 34/180, 34 UN GAOR supp (No 46) at 193, UN Doc A/34/46 (1979).

89 Optional Protocol to the Convention on the Elimination of All Forms of Discrimination against Women, UN General Assembly Res 54/4, Annex, 54 UN GAOR supp (No 49) at 5 UN Doc A/54/49 (Vol I) (2000).

${ }^{90}$ General Recommendation No 28 on the Core Obligations of States Parties under Article 2 of the Convention on the Elimination of All Forms of Discrimination against Women, UN GAOR, Committee on Elimination of Discrimination Against Women, 47th Sess, 12, UN Doc CEDAW/C/GC/28 (2010) para 12.

${ }^{91}$ International Convention on the Elimination of All Forms of Racial Discrimination, [1966] 660 UNTS 195.

92 Art 3 CERD provides that 'States Parties particularly condemn racial segregation and apartheid and undertake to prevent, prohibit and eradicate all practices of this nature in territories under their jurisdiction' (emphasis added).

93 Application of the International Convention on the Elimination of all Forms of Racial Discrimination (Georgia v Russian Federation), Provisional Measures, [2008] ICJ Reports 358, 398 [149] (emphasis added).

94 Convention on the Rights of the Child, UN General Assembly Res 44/25, Annex, UN GAOR supp (No 49) at 167, UN Doc A/44/49 (1989).

95 Art 2(1) CRC.
} 
accordance with international law, the Committee has previously urged States to protect the rights of children who may be beyond their territorial borders. It has also emphasized that State obligations under the Convention and the Optional Protocols thereto apply to each child within a State's territory and to all children subject to a State's jurisdiction. ${ }^{96}$

59.39 In addition, the CRC contains some duties with specific extraterritorial aspects, such as Article 3(1) of the Optional Protocol on the sale of children, child prostitution, and child pornography, ${ }^{97}$ which requires states to enact legislation to criminalise specific offences against children when committed by their nationals in the territory of another state. The CRC also contains specific duties of international cooperation. ${ }^{98}$

\section{CRPD}

59.40 In relation to the Convention on the Rights of Persons with Disabilities (CRPD), ${ }^{99}$ Article 1(1) of the Optional Protocol provides that the Committee has competence to hear communications from those within the 'jurisdiction' of the State Party concerned. ${ }^{100}$ The EU was instrumental in the drafting of the CRPD and has ratified the Convention, ${ }^{101}$ but not the Optional Protocol. ${ }^{102}$ The Convention also contains a detailed provision on international cooperation. ${ }^{103}$

96 General Comment No 16 (2013) on State obligations regarding the impact of the business sector on children's rights (CRC/C/CG/16) 17 April 2013, para 39, citing General Comment No 6 (2005) on treatment of unaccompanied and separated children outside their country of origin, (A/61/41), para 12. See further P Gerber, J Kyriakakis and K O'Byrne, 'General Comment 16 on State Obligations Regarding the Impact of the Business Sector on Children's Rights, What is its Standing, Meaning and Effect?' (2013) 14 Melbourne Journal of International Law 93.

97 Optional Protocol to the Convention on the Rights of the Child on the sale on children, child prostitution and child pornography, UN General Assembly Res 54/263, Annex II, 54 UN GAOR supp (No 49) at 6, UN Doc A/61/49 (2006).

98 See, for example, Arts 11, 21, 22, 27, and 30 CRC, and the Optional Protocol to the CRC on the involvement of children in armed conflicts (Art 7) and in the Optional Protocol to the CRC on the sale of children, child prostitution and child pornography (Art 10).

99 International Convention on the Protection and Promotion of the Rights and Dignity of Persons with Disabilities, UN General Assembly Res 61/106, Annex I, UN GAOR supp (No 49) at 65, UN Doc A/61/49 (2006).

100 First Optional Protocol to the International Convention on the Protection and Promotion of the Rights and Dignity of Persons with Disabilities, UN General Assembly Res 61/106, Annex II, UN GAOR supp (No 49 ) at 80 , UN Doc A/61/49 (2006).

${ }^{101}$ G De Búrca, 'The EU in the Negotiation of the UN Disability Convention' (2010) 35 European Law Review 174.

102 European Commission Press Release, 'EU ratifies UN Convention on disability rights', IP/11/4, 5 January 2011, available at, http,//europa.eu/rapid/press-release_IP-11-4_en.htm.

103 Art 32 CRPD establishes that:

'1. States Parties recognize the importance of international cooperation and its promotion, in support of national efforts for the realization of the purpose and objectives of the present Convention, and will undertake appropriate and effective measures in this regard, between and among States and, as appropriate, in partnership with relevant international and regional organizations and civil society, in particular organizations of persons with disabilities. Such measures could include, inter alia,

a. Ensuring that international cooperation, including international development programmes, is inclusive of and accessible to persons with disabilities;

b. Facilitating and supporting capacity-building, including through the exchange and sharing of information, experiences, training programmes and best practices;

c. Facilitating cooperation in research and access to scientific and technical knowledge;

d. Providing, as appropriate, technical and economic assistance, including by facilitating access to and sharing of accessible and assistive technologies, and through the transfer of technologies.

2. The provisions of this article are without prejudice to the obligations of each State Party to fulfil its obligations under the present Convention.' 
The European Union made an elaborate Declaration on ratifying the CRPD. ${ }^{104}$ As regards its territorial scope, the EU's Declaration states that the CRPD applies 'with regard to the competence of the European Community, to the territories in which the Treaty establishing the European Community is applied and under the conditions laid down in that Treaty, in particular Article 299 thereof. ${ }^{\prime 105}$ The Declaration notes that the competences of the EU evolve, but describes the existing competences that are pertinent to the CRPD. Amongst the mentioned policy areas is 'development cooperation policy and economic, financial and technical cooperation with third countries without prejudice to the respective competences of the Member States.' ${ }^{106}$ The Appendix to the Declaration includes amongst the 'Community Acts which refer to matters governed by the Convention' Regulations on development cooperation and promotion of democracy and human rights worldwide. ${ }^{107}$

\section{Refugee Convention}

The 1951 Refugee Convention has a differentiated territorial scope. ${ }^{108}$ While nonrefoulement, together with other provisions not subject to qualification, ${ }^{109}$ may apply extraterritorially, ${ }^{110}$ some rights are reserved for those 'present in' the state party's territory, ${ }^{111}$ refugees 'lawfully staying' in the country of refuge, ${ }^{112}$ and refugees who have their 'habitual residence' in the state party concerned. ${ }^{113}$

\section{ECHR}

There is an extensive case law examining the meaning of 'jurisdiction' under Article 1 ECHR, evidencing considerable changes over time. ${ }^{114}$ The jurisprudence has evolved significantly from the Court's falter on the ill-conceived espace juridique notion in

104 See Status of the Convention, Declarations and Reservations, EU Declaration to the CRPD, at http:// treaties.un.org/Pages/ViewDetails.aspx?src=TREATY\&mtdsg_no=IV-15\&chapter=4\&lang=en\#EndDec.

105 Preamble to the EU Declaration to the CRPD.

106 EU Declaration to the CPRD [3].

107 Regulation (EC) 1905/2006 establishing a financing instrument for development cooperation [2006] OJ L378/41; Regulation (EC) 1889/2006 on establishing a financing instrument for the promotion of democracy and human rights worldwide [2006] OJ L386/1.

108 Rights accrue to refugees depending on their level of attachment to the receiving state. See GoodwinGill and McAdam (n 84) 524 et seq; and JC Hathaway, The Rights of Refugees under International Law (Cambridge, CUP, 2005) 154 et seq.

109 See, eg, Art 3 (non-discrimination among refugees) and Art 16(1) (access to courts).

110 For a detailed analysis, see V Moreno-Lax, 'Must EU Borders have Doors for Refugees?' (2008) 10 European Journal of Migration and Law 315; V Moreno-Lax, '(Extraterritorial) Entry Controls and (Extraterritorial) Non-Refoulement in EU Law', in M Maes, M-C Foblets and P De Bruycker (eds), The External Dimensions of EU Asylum and Immigration Policy, (Brussels, Bruylant, 2011) 385; and V Moreno-Lax, 'Seeking Asylum in the Mediterranean', (2011) 23 International Journal of Refugee Law 174.

111 See, eg, Art 31 (exemption from penalties on account of illegal entry) and Art 4 (freedom of religion).

112 See, eg, Art 15 (right of association), Art 17 (employment), Art 19 (access to liberal professions).

113 See, for instance, Art 7(2) (exemption from reciprocity), Art 14 (artistic rights), and Art 16(2) (cautio judicatum solvi).

114 See generally, O De Schutter, International Human Rights Law (Cambridge, CUP, 2010), ch 2 'State Responsibility and Jurisdiction', 123. The account here draws on C Costello, 'Courting Access to Asylum in Europe, Recent Supranational Jurisprudence Explored' (2012) 12 Human Rights Law Review 287. 
Banković ${ }^{115}$ to the 2011 Grand Chamber ruling in Al-Skeini. ${ }^{116}$ We provide a summary of this development. Most noteworthy is the fact that the ECHR interpretation of 'jurisdiction' appears more difficult to meet that that of some other bodies, such as the HRC interpreting the ICCPR.

59.44 Banković ${ }^{117}$ concerned victims of the NATO bombing of Belgrade in 1999. The ECtHR's starting premise in that case was that one state's jurisdiction is normally 'defined and limited by the sovereign territorial rights of ... other relevant States', 118 so that Article 1 ECHR should be interpreted 'to reflect this ordinary and essentially territorial notion of jurisdiction. ${ }^{119}$ Accordingly, extraterritorial jurisdiction only arose in 'exceptional cases', ${ }^{120}$ where the respondent state exercised effective control over another territory or over a person abroad. In the intervening years, the Court moved away from the espace juridique notion, and found jurisdiction in several cases not dissimilar to Banković. ${ }^{121}$ Finally in Al-Skeini, the Grand Chamber expressly abandoned both the espace juridique formula ${ }^{122}$ and its objection to 'dividing and tailoring' jurisdiction. ${ }^{123}$ In Banković, the Court had rejected the applicability of any human rights obligations on the basis that all human rights obligations could not be applied by the respondent states, as they did not exercise effective control over Belgrade. However, this objection is puzzling and was expressly abandoned in Al-Skeini. This case concerned the killing of six Iraqi nationals by British troops in Iraq. In contrast to the Bankovic approach, the ECtHR held that all the applicants were under UK jurisdiction, not based on control over the territory of Southern Iraq, but rather focused on the UK's exercise of 'public powers normally to be exercised by a sovereign government, ${ }^{124}$ resulting from the pertinent UN Security Council Resolutions and regulations of the Coalition Provisional Authority in Iraq. ${ }^{125}$

59.45 In brief, there appear to be three approaches, one based on control over territory, a second based on control over persons and, arguably, in light of Al-Skeini, a third based on a combination of the territorial and personal factors against a background exercise of public powers. The thresholds of 'effective control' in the first two scenarios are high, such that Klug and Howe argue that the ECtHR standard 'seems to be much higher than

115 Banković (n 21) [80].

116 Al-Skeini v United Kingdom (n 22). See P Ronchi, 'The Borders of Human Rights' (2012) 128 Law Quarterly Review 20; M Milanovic 'Al-Skeini and Al-Jedda in Strasbourg' (2012) 23 European Journal of International Law 121.

117 Above n 115.

118 Ibid [59].

119 Ibid [61].

120 Ibid [67].

121 Issa $v$ Turkey App no 31821/96 (ECtHR, 16 November 2004); Pad and others $v$ Turkey App no 60167/00 (ECtHR, Admissibility 28 June 2007); Isaak and others $v$ Turkey App no 44587/98 (ECtHR, 28 September 2007).

${ }^{122}$ Al-Skeini v United Kingdom (n 22) [142]. The concept had been powerfully criticised. See, for example, O Ben-Naftali and Y Shany, 'Living in Denial, The Co-application of Humanitarian Law and Human Rights Law to the Occupied Territories', (2004) 37 Israel Law Review 17; R Wilde, 'The "legal space" or "espace juridique" of the European Convention on Human Rights, is it relevant to extraterritorial State action?' (2005) 10 European Human Rights Law Review 115.

123 Al-Skeini v United Kingdom (n 22) [137].

124 Ibid [149].

125 Ibid [143]-[148]. 
that adopted by other supervisory bodies. ${ }^{126}$ The third is less clearly defined and suggests that further case law will be required to refine the interpretation.

\section{(a) EU Accession to the ECHR}

EU accession to the ECHR has been long contemplated, and is now in train. ${ }^{127}$ Accession of the EU to the ECHR will bring all EU action under the purview of the ECtHR, even in those fields where the CJEU does not have full oversight, such as CFSP measures. ${ }^{128}$ Accordingly, it is anticipated that in some fields, it will increase the role of the ECtHR. ${ }^{129}$ Currently the ECtHR only exercises a form of indirect scrutiny over the EU, under its Bosphorus doctrine. ${ }^{130}$

For the purposes of this chapter, the most interesting aspect of EU accession to the ECHR is how the EU will deal with Article 1 ECHR. The answer, in the draft agreement on accession, is that it seeks to create a mirror image of the understanding of 'jurisdiction' that pertains to States Parties. ${ }^{131}$ So, if a question is raised about whether someone falls within the EU's 'jurisdiction' for the purposes of determining whether the EU may be brought before the ECtHR, the answer will be yes, if, and only if, the person in question is within the jurisdiction of an EU Member State. It is acknowledged that such jurisdiction may arise by being physically within the EU, or in an extraterritorial scenario that would be deemed to be within a Member State's jurisdiction. ${ }^{132}$ The drafting means that if the understanding of 'jurisdiction' evolves (as it surely will), the evolution will equally apply to the EU/Member State context. ${ }^{133}$ The fact that the EU's duties under the ECHR will be subject to Article 1 ECHR is, however, not relevant to the question of the scope of application of EU fundamental rights and the Charter within the EU legal context as a matter of EU law.

\footnotetext{
126 Klug and Howe, above n 74, 99.

127 T Lock, 'End of an Epic? The Draft Agreement on the EU's Accession to the ECHR' (2012) 31 Yearbook of European Law 162, analysing CDDH(2011)009; C Eckes 'EU Accession to the ECHR, Between Autonomy and Adaptation' (2013) 76 The Modern Law Review 254. For a detailed study, see P Gragl, The Accession of the European Union to the European Convention on Human Rights (Oxford, Hart, 2013) and his analysis of the accession agreement in this commentary.

128 See Art 275 TFEU, which allows CJEU jurisdiction only over CFSP decisions providing for restrictive measures against natural or legal persons within the meaning of Art 215(2) TFEU.

129 See Eckes (n 127), 282-83, noting that, 'The EU is carrying out multiple peace keeping missions under the CFSP that could lead to potential complaints before the ECtHR ... The EU's accession to the ECHR will improve human rights protection of individuals in the EU, despite the fact that it adds to complexity.'

130 Bosphorus $v$ Ireland App no 45036/98 (ECtHR [GC], 30 June 2005).

131 Draft Agreement on the European Union's Accession to the European Convention on Human Rights, Strasbourg, 10 June 2013, 47+1(2013)008 rev 2.

132 Ibid, Art 1(6) provides that [i]nsofar as the expression "everyone within their jurisdiction" appearing in Article 1 of the Convention refers to persons within the territory of a High Contracting Party, it shall be understood, with regard to the European Union, as referring to persons within the territories of the Member States of the European Union to which the Treaty on European Union and the Treaty on the Functioning of the European Union apply. Insofar as this expression refers to persons outside the territory of a High Contracting Party, it shall be understood, with regard to the European Union, as referring to persons who, if the alleged violation in question had been attributable to a High Contracting Party which is a State, would have been within the jurisdiction of that High Contracting Party.' Moreover the Draft Agreement also clarifies that when the Convention refers to 'country' or 'territory of a State', it 'shall mean each of the territories of the Member States of the European Union to which the Treaty on European Union and the Treaty on the Functioning of the European Union apply.'

133 Ibid, Art 1(7).
} 


\section{(b) EU's Extraterritorial Legislation and (Its Non-consideration of) 'IHRL Jurisdiction'}

59.48 The above sections have shown that to act, the EU must have competence. PIL jurisdiction has informed how competences shall be determined in extraterritorial scenarios. On the other hand, IHRL has its own distinct notion of IHRL jurisdiction. In this sub-section, we illustrate that when the EU legislates in order to act extraterritorially, it often acknowledges (certain) human rights duties. Of course, our main argument is not dependent on this explicit acknowledgement. Nonetheless, the legislation recognises the applicability of (at least some) EU fundamental rights norms in extraterritorial contexts, without any threshold assessment of IHRL jurisdiction being required. The external dimension of Justice and Home Affairs, and the Common Foreign and Security Policy illustrate the point.

\section{(c) Area of Freedom, Security and Justice}

59.49 The Area of Freedom, Security and Justice has a strong external dimension, as exemplified by EU legislation on movement across the external borders and the fight against irregular migration.

59.50 At first sight, the non-refoulement protections found in this field may seem to draw on Strasbourg jurisprudence and appear tacitly inspired by the 'effective control' model. For instance, in the revised Frontex Regulation, ${ }^{134}$ Article 2(1a) establishes that ' $\left.\mathrm{i}\right] \mathrm{n}$ accordance with Union and international law, no person shall be disembarked in, or otherwise handed over to the authorities of, a country in contravention of the principle of non-refoulement, or from which there is a risk of expulsion or return to another country in contravention of that principle.' ${ }^{135}$ In this instance 'disembarkation' and 'hand over' are actions that have already been considered to entail 'effective control' and thus triggered the protection against ill-treatment enshrined in the ECHR, notwithstanding such control being exercised extraterritorially. ${ }^{136}$ The provision could, therefore, be perceived by some as a mere codification in EU law of an ECHR obligation common to all Member States. However, EU law in this area does not rely on the 'effective control' paradigm, in that not only concrete instances of IHRL jurisdiction may prompt the application of EU fundamental rights.

59.51 Article 2(1a) of the revised Frontex Regulation cannot be taken in isolation; its territorial scope is determined by the Schengen Borders Code. ${ }^{137}$ That instrument defines

\footnotetext{
134 Regulation (EU) 1168/2011 amending Council Regulation (EC) 2007/2004 establishing a European Agency for the Management of Operational Cooperation at the External Borders of the Member States of the European Union [2011] OJ L304/1.

${ }_{135}$ A similar clause has now been added to the Schengen Borders Code in Art 3a. See Regulation (EU) 610/2013 amending Regulation (EC) 562/2006 establishing a Community Code on the rules governing the movement of persons across borders (Schengen Borders Code), the Convention implementing the Schengen Agreement, Council Regulations (EC) 1683/95 and (EC) 539/2001 and Regulations (EC) 767/2008 and (EC) 810/2009 of the European Parliament and of the Council [2013] OJ L182/1.

136 Hirsi Jamaa and others v Italy App no 27765/09 (ECtHR, 23 February 2012). For analysis see V MorenoLax, 'Hirsi Jamaa and others $v$ Italy or the Strasbourg Court versus Extraterritorial Migration Control?' (2012) 12 Human Rights Law Review 574.

137 See Art 16, Regulation (EC) 562/2006 establishing a Community Code on the rules governing the movement of persons across borders (Schengen Borders Code) [2006] OJ L 105/1 (SBC hereinafter).
} 
borders not only territorially, but also functionally, comprising explicit rules on extraterritorial border controls. ${ }^{138}$ For example, Article 2(2) SBC defines 'external borders' in territorial terms, as enclosing 'the Member States' land borders, including river and lake borders, sea borders and their airports, river ports, sea ports, provided that they are not internal borders'. On the other hand, when defining the 'specific rules for the various types of border and the various means of transport used for crossing the Member States' external borders, ${ }^{139}$ the Code replaces the geographical criterion with a functional one. With regard to rail traffic, Annex VI SBC establishes that checks can be performed in stations in a third country where persons board the train. ${ }^{140}$ At sea, 'checks may also be carried out ... in the territory of a third country'. ${ }^{141}$ Apparently, it is on account of the function these controls fulfil that the Code accords a scope of application that extends beyond the territories of the Member States.

The possibility of extraterritorial application of the SBC was expressly part of the European Parliament's action to annul the Council Decision on Frontex's coordination of maritime border surveillance, ${ }^{142}$ which included rules on interdiction at sea broadly construed, introducing various coercive measures applicable both in territorial waters and on the high seas. ${ }^{143}$ The Court annulled the instrument as exceeding the powers delegated in the SBC, but did not explicitly resolve on the territorial scope point. ${ }^{144}$ Nonetheless, the Court noted that the measures contemplated in the Decision were liable ... to interfere with the sovereign rights of third countries according to the flag flown by the ships concerned.' ${ }^{45}$ The Advocate General had, by contrast, dealt explicitly with the issue, acknowledging the principle of freedom of navigation and of exclusive PIL jurisdiction of the flag state. Crucially, he noted that the rules impugned, 'intending to ensure uniform application of relevant international law', were such as to '[potentially] bring ... [the Member States'] international responsibility into play', ${ }^{146}$ signalling that actions coordinated by Frontex did not release Member States' PIL duties. ${ }^{147}$ What both the

138 For a detailed discussion on this point and further references, see $\mathrm{M}$ den Heijer, 'Europe beyond its Borders, Refugee and Human Rights Protection in Extraterritorial Immigration Control', in B Ryan and V Mitsilegas (eds), Extraterritorial Immigration Control (Leiden/Boston, Brill, 2010) 169, 176-80. See also V Moreno-Lax, '(Extraterritorial) Entry Controls and (Extraterritorial) Non-Refoulement in EU Law' (n 110).

139 Title of Annex VI SBC.

140 Para 1.2.2. Annex VI SBC (emphasis added).

141 Para 3.1.1. Annex VI SBC (emphasis added).

142 Council Decision 2010/252/EU supplementing the Schengen Borders Code as regards the surveillance of the sea external borders in the context of operational cooperation coordinated by the European Agency for the management of Operational Cooperation at the External Borders of the Member States of the European Union [2010] OJ L111/20. For a critique, see V Moreno-Lax, 'The EU Regime on Interdiction, Search and Rescue, and Disembarkation, The Frontex Guidelines for Intervention at Sea' (2010) 25 The International Journal of Marine and Coastal Law 621.

143 Case C-355/10 Parliament v Council (Judgment 5 September 2012).

144 Ibid [84]. Note, however, that the Court maintains the effects of the Decision in para 90, until a replacement instrument enters into force. As a result of this ruling, the Commission proposed legislation on this topic, which has yet to be agreed. See Proposal for a Regulation establishing rules for the surveillance of the external sea borders in the context of operational cooperation coordinated by the European Agency for the Management of Operational Cooperation at the External Borders of the Members States of the European Union (Frontex), COM (2013) 197 final.

145 Ibid [76].

146 Opinion of AG Mengozzi in Case C-355/10 Parliament v Council (17 April 2012) [50].

147 Ibid [63]. For analysis of the disputed character of Search and rescue duties in the Mediterranean, see S Klepp 'A Double Bind, Malta and the Rescue of Unwanted Migrants at Sea, a Legal Anthropological Perspective on the Humanitarian Law of the Sea' (2011) 23 International Journal of Refugee Law 538. 
Advocate General and the Court underlined was that the extraterritorial measures contemplated in the Decision could interfere with fundamental rights. ${ }^{148}$

59.53 Recent amendments to Annex VI SBC now detail the regime applicable to 'shared border crossing points' located on third-country territory 'pursuant to a bilateral agreement', 149 including an attempt to delineate international protection rules for that scenario. ${ }^{150}$ The reform also introduces a new Article 3a SBC, explicitly requiring Member States to 'act in full compliance with ... fundamental rights'. The revision demonstrates that, in order to act extraterritorially, a basis in PIL jurisdiction is necessary (the bilateral agreement) and that it is essential to ensure all actions respect, protect and promote human rights. Our central argument, that EU fundamental rights follow EU action, means that the text of these legislative developments, though welcome, is not essential. Rather, fundamental rights apply as a matter of EU constitutional obligation, with or without an explicit acknowledgment in secondary law and without any additional IHRL jurisdictional criteria having to be met.

\section{(d) Common Foreign and Security Policy}

59.54 By its very nature, the Common Foreign and Security Policy (CFSP) is external, and sometimes extraterritorial. ${ }^{151}$ As already mentioned, the Treaties subordinate EU action in the international domain 'to the strict observance and the development of international law, ${ }^{152}$ including 'the universality and indivisibility of human rights and fundamental freedoms, ${ }^{153}$ which rank among the principles on which the Union is founded. ${ }^{154}$ These principles shall guide the Union in the development and implementation of the different areas of [its] external action ... and of the external aspects of its other policies. ${ }^{155}$

59.55 One example of EU extraterritorial action arises under EUNAVFOR (the EU Naval Force) Somalia, ${ }^{156}$ which authorises entry into the territorial waters of Somalia and the use of force necessary to repress acts of piracy and armed robbery at sea. ${ }^{157}$ To that effect, the EU instrument envisages that persons having committed or suspected of having committed an act of piracy or armed robbery may be detained and transferred to third countries participating in the operation. ${ }^{158}$ At the same time, the measure acknowledges that when EU or national authorities implement these measures, the

\footnotetext{
148 Parliament $v$ Council (n 143) [77].

149 Art 1(8)(a), Regulation 610/2013 (n 135).

150 Annex VI, Point 1.1.4, Regulation 610/2013 (n 135).

151 Arts 21-46 TEU.

152 Art 3(5) TEU.

153 Art 21(1) TEU.

154 Art 2 TEU and Kadi (n 15).

155 Art 21(3) TEU. See also Art 23 TEU.

156 See Council Joint Action 2008/851/CFSP of 10 November 2008 on a European Union military operation to contribute to the deterrence, prevention and repression of acts of piracy and armed robbery off the Somali coast [2008] OJ L 301/33. The Preamble mentions UNSC Resolutions 1814 (2008), 1816 (2008), and 1838 (2008), relating to the situation in Somalia.

157 Recital 2 and Arts 1-2, Joint Action 2008/851/CFSP.

158 Arts 10 and 12(1), Joint Action 2008/851/CFSP.
} 
Charter and the general principles apply. ${ }^{159}$ The clause is reminiscent of the one found in the Frontex Regulation, further demonstrating the extraterritorial applicability of EU fundamental rights law.

\section{Analysis: The Applicability of EU Fundamental Rights, an Autonomous Paradigm}

It has already been pointed out that the Charter has no jurisdictional clause of the type we find in Article 1 ECHR or Article 2 ICCPR. It has also been underlined that the Union, as an international organisation, does not possess sovereign territory of its own, making recourse to territorial parameters to define the reach of its provisions ill-suited. Nor does attempting to answer statist questions such as when does the EU have 'effective control' over persons or territory yield useful responses in the EU context. Rather, the Charter's field of application is autonomously regulated by the 'general provisions governing the interpretation and application of the Charter' inscribed in Title VII, ${ }^{160}$ independently of IHRL jurisdiction and similarly extraneous constraints.

Article 51 governs the remit of the Charter, while Articles 52 and 53, as the relevant chapters of this volume elucidate, govern the interpretation of the rights and principles contained therein. ${ }^{161}$ As mentioned above, Article 51(1) lists the addressees of Charter obligations, stipulating that the Charter applies to both EU organs and the Member States when they 'implement' EU law provisions. In turn, Article 51(2) clarifies that the Charter does not extent the field of application of EU law beyond the powers conferred on the organisation, nor does it establish any new competence or modify those defined in the founding Treaties. ${ }^{162}$ The language, therefore, is that of competences, allocation of powers and their application within the realm of the EU legal order, ${ }^{163}$ irrespective of the geographical space within which these powers may be exercised. The scope of application ratione loci of the Charter is, accordingly, to be determined by reference to the general scope of application of EU law, following autonomous requirements. ${ }^{164}$ The

159 This is made clear in particular by Art 12(2) of the Joint Action, which introduces a limit to the powers of repression that EU representatives may exercise in the form of a non-refoulement safeguard that applies in these situations. Persons arrested or detained in the course of the Atalanta operation, whether in Somali waters or on the high seas, may not be transferred to a third state, 'unless the conditions for the transfer have been agreed with that third State in a manner consistent with relevant international law, notably international law on human rights, in order to guarantee in particular that no one shall be subjected to the death penalty, to torture or to any cruel, inhuman or degrading treatment'.

160 On the horizontal provisions generally, see above $\mathrm{n} 2$.

161 For a similar argument, refer to S Iglesias Sánchez, 'The Court and the Charter, The Impact of the Entry into Force of the Lisbon Treaty on the ECJ's Approach to Fundamental Rights' (2012) 49 Common Market Law Review 1565, 1584.

162 See also Art 6(1) TEU and Declaration 1 of the Final Act of the Treaty of Lisbon. The Czech Declaration on the Charter and the Polish Protocol reiterate this phrasing. For a judicial assertion, see Dereci (n 27) [71].

163 On this point see P Eeckhout, 'The EU Charter of Fundamental Rights and the Federal Question' (2002) 39 Common Market Law Review 945.

164 For an elaboration on EU autonomous requirements and their implications for the interpretation of the horizontal clauses of the Charter, with special reference to the right to liberty and security of person (Art 6), see V Moreno-Lax, 'Beyond Saadi v UK, Why the "Unnecessary" Detention of Asylum Seekers is Inadmissible under EU Law’ (2011) 5 Human Rights and International Legal Discourse 166, 195 et seq. 
Charter applies to a particular situation once EU law governs it. There is no additional criterion, of a territorial character or otherwise, that needs to be fulfilled in this context. ${ }^{165}$ The point, therefore, is not to identify an independent field of application of the Charter, but to determine the remit of EU law and its relevance to a particular situation. ${ }^{166}$

59.58 The Charter applies whenever the institutions, bodies, offices and agencies of the Union exercise their powers. ${ }^{167}$ It also does when the Member States 'are implementing EU law'. The meaning of 'implementing' in Article 51 was subject to some initial scholarly controversy, ${ }^{168}$ but the Court has now clarified that the Charter applies as the general principles did, that is whenever Member States 'act within the scope of Union law'. ${ }^{169}$ In other words, the Charter concerns all EU acts and 'all situations where Member States fulfil their obligations under ... EU law'. ${ }^{170}$ 'Implementation', accordingly, has been given a wide interpretation. ${ }^{171}$ Exercising a broad discretionary option under EU law will be treated as 'implementing EU law. ${ }^{172}$ Even where EU secondary rules defer expressly to Member State preferences through direct reference to national law, the Court of Justice has understood that such references 'do not mean that the Member States may undermine the effectiveness of [EU law]'. ${ }^{173}$ Such implementing decisions 'must comply with the rights and observe the principles provided for under the Charter.' ${ }^{174}$ In implementing, Member States are not permitted to jeopardise the exercise of fundamental rights conferred on individuals by EU law. ${ }^{175}$

59.59 The principle of effectiveness typically leads to a broad construction of EU obligations, limiting Member States' discretion. National rules may not 'have either the object or the effect of creating an obstacle' to the enjoyment of EU rights. ${ }^{176}$ The 'obstacle'

165 A similar point was put forward in relation to the personal scope of application of the Charter by S Peers in 'Immigration, Asylum and the European Union Charter of Fundamental Rights' (2001) 3 European Journal of Migration and Law 141, 146-48. See also D Curtin, 'The Sting is Always in the Tail, The Personal Scope of Application of the EU Charter of Fundamental Rights' (2001) 8 Maastricht Journal 102.

166 Case C-400/10 PPU McB [2010] ECR I-8965 [51].

167 See, for instance, Case C-377/98 The Netherlands $v$ Parliament and Council [2001] ECR I-7079 (legislative); Case C-404/92 P X v Commission [1994] ECR I-4737 (executive); and Case C-185/95 P Baustahlgewebe $v$ Commission [1998] ECR I-8417 (judicial).

168 See, eg Chalmers et al, European Union Law, 2nd edn (Cambridge, CUP, 2010) 255, stating that it is 'stretching credulity' that 'implementing' meant the same as the previous case law on the scope of fundamental rights qua general principles.

169 This includes (1) when they implement EU obligations, (2) when they apply or restrict provisions of primary or secondary legislation, or (3) when they derogate from EU legal requirements. See Explanations to the Charter of Fundamental Rights [2007] OJ C303/02, 32, referring to Case 5/88 Wachauf [1989] ECR 2609; Case C-260/89 ERT [1991] ECR I-2925; Case C-309/96 Annibaldi [1997] ECR I-7493.

$170 \mathrm{~K}$ Lenaerts, 'Exploring the Limits of the EU Charter of Fundamental Rights' (2012) 8 European Constitutional Law Review 375, 378.

${ }^{171}$ In this vein, see L Burgorgue-Larsen, 'Chronique de jurisprudence européenne comparée' (2011) 4 Revue du droit public 1022.

172 Joined Cases C-411/10 and C-493/10 NS \& ME (Judgment 21 December 2011) [64]-[68]. For analysis, see C Costello, 'The Ruling of the Court of Justice in NS/ME on the fundamental rights of asylum seekers under the Dublin Regulation, Finally, an end to blind trust across the EU?' (2012) Asiel-en Migrantenrecht 83.

173 Case C-571/10 Kamberaj (Grand Chamber, Judgment 24 April 2012) [78].

174 Ibid. [80].

175 Case C-502/10 Singh (Judgment 18 October 2012) [51]; Case C-508/10 Commission $v$ The Netherlands (Judgment 26 April 2012) [65], [73].

176 Case C-508/10 Commission v The Netherlands (Judgment 26 April 2012) [69]. 
approach is also prevalent in the EU Citizenship case law, ${ }^{177}$ bringing with it a duty to respect EU fundamental rights. ${ }^{178}$ The scope of EU law in this context is still evolving, as is evident in the case law on third-country national family members. ${ }^{179}$ In that context, Zambrano has marked an inflection point. Thereafter, Member State actions liable to impair 'the genuine enjoyment of the substance of the rights conferred by virtue of their status as citizens of the Union' fall within the scope of EU law. ${ }^{180}$ Although the precise contours of the 'genuine enjoyment' paradigm are yet to be determined, ${ }^{181}$ the case illustrates the importance of the principle of effectiveness in their delimitation.

Mangold ${ }^{182}$ and Kücükdeveci ${ }^{183}$ further attest to the expansive notion of the scope of EU fundamental rights law. In those cases national rules were deemed to come within the scope of EU law by virtue of dealing with substantive matters governed by EU directives, triggering the application of EU fundamental rights principles. ${ }^{184}$ Fransson appears to set a new high water mark for this expansive scope. ${ }^{185}$ The case concerned national rules on VAT penalties and criminal liability. Although the national rules in question did not implement any specific EU legislative provision, the coincidence of subject matter between domestic measures and the objectives of EU law was sufficient to mean that there was implementation 'for the purposes of Article 51(1) of the Charter.' ${ }^{186}$ The full implications remain to be seen, but, if the ruling consolidates in subsequent case law, Fransson may render the Charter applicable to further Member State action. The language of the case, speaking of fields 'connected in part to' EU law or 'affecting the ... interests of the European Union', suggests a very broad scope for the Charter vis-à-vis the Member States. ${ }^{187}$ Of course, this is not to suggest that the Charter applies to all Member State action or that it should. Some matters remain clearly outside the scope of EU law. ${ }^{188}$ The purpose of this exposition is simply to illustrate the role of the principle

177 See, for instance, Joined Cases C-11/06 and C-12/06 Morgan [2007] ECR I-9161; Case C-192/05 Tas Hagen [2006] ECR I-10451; Case C-499/06 Nerkowska [2008] ECR I-3993.

178 See, for example, Case C-60/00 Carpenter [2002] ECR I-6279.

179 Case C-127/08 Metock [2008] ECR I-6241. For commentary, see C Costello, 'Metock, Free movement and "normal family life" in the Union' (2009) 46 Common Market Law Review 587. More recently, see also Case C-40/11 Iida (Judgment 8 November 2012) [63], [68].

180 Zambrano ( $\mathrm{n} 27$ ) [42] et seq. The case has given rise to a heated debate. See, for instance, K Hailbronner and D Thym, 'Annotation of Case C-34/09 Ruiz Zambrano' (2010) 48 Common Market Law Review 1253. Cf N Shuibhne '(Some Of) The Kids Are All Right, Comment on McCarthy and Dereci' (2012) 49 Common Market Law Review 349.

181 The Court has limited this to the most extreme circumstances, contemplating only 'situations in which the Union citizen has, in fact, to leave not only the territory of the Member State of which he is a national but also the territory of the Union as a whole'. See McCarthy (n 27) [53] et seq; and Dereci (n 27) [66].

182 Case C-144/04 Mangold [2005] ECR I-9981.

183 Case C-555/07 Kücükdeveci [2010] ECR I-365.

184 For discussion and concern about this development, see Editorial comment, 'The Scope of Application of the General Principles of Union Law, An Ever Expanding Union?' (2010) 47 Common Market Law Review 1589,1593 et seq.

185 Fransson (n 3). The same approach is evident in Case C-418/11 Texdata (Judgment 26 September 2013).

186 Ibid [29].

187 Ibid [24], [26]. See also ibid [29], speaking of 'a situation where action of the Member States is not entirely determined by European Union law', which, nonetheless, 'implements the latter for the purposes of Article 51(1) of the Charter'.

188 See, among others, Case C-299/95 Kremzow [1997] ECR I-2629; Case C-328/04 Vajnai [2005] ECR I-8577; Case C-13/05 Chacón Navas [2006] ECR I-6467. 
of effectiveness, as an autonomous requirement, in determining the construction of the scope of application of EU law.

\section{E. Evaluation: The Emergence of a New Model}

59.61 The EU is bound by its own fundamental rights catalogues, namely the Charter and the general principles, whenever it exercises its competences, both internally and externally, either directly or through the intermediation of the Member States 'implementing EU law'. As the Charter requires that rights and principles be 'observed and promoted', ${ }^{189}$ failures to act are also relevant, with omissions being equally answerable to fundamental rights. The territorial clauses in the TEU and the TFEU do not create an obstacle to the extraterritorial applicability of EU law. This is not only supported by the functional understanding of the applicability threshold of EU rules that several instruments endorse, but also by relevant and sustained jurisprudence of the Court of Justice, as examined above. In consequence, the discussion on the extraterritorial applicability of the Charter should be liberated from the often politically laden debate on borders and territory and brought to the less-statist space of EU competences and legality.

59.62 Whenever EU law applies, indeed wherever the EU acts, it must respect, protect and promote fundamental rights, within the scope of its competences as a matter of EU law. The approach need not lead to an expansion of EU powers, nor should it affect the allocation of competences as configured by the EU Treaties. The point is rather the reverse. It consists in the affirmation that whenever EU law applies-as according to the Treaties - the Charter applies too. The precise duties will depend on the particulars of the case. Our arguments are about accountability and legality: there cannot be 'legal black holes' where the EU acts, but fundamental rights are not applicable. Respect for fundamental rights constitutes one of the essential values on which the Union and its legal system are founded. ${ }^{190}$ The key question, therefore, is not whether the Charter applies territorially or extraterritorially, but whether a particular situation falls to be governed by EU law or not. If that is the case, the application of the Charter follows automatically.

59.63 Articles 2 and 3(5) TEU place both 'respect for human rights' and 'the strict observance ... of international law' as EU constitutional fundamentals. ${ }^{191}$ Actually, according to the TEU, the EU shall act in the international scene in order to 'consolidate and support democracy, the rule of law, human rights and the principles of international law, ${ }^{192}$ taking fundamental rights into account not only in the implementation, but also in the design and 'the development ... of the Union's external action ... and of the external aspects of its other policies, ${ }^{193}$ fostering 'a high degree of cooperation in all

\footnotetext{
189 Art 51(1) CFR.

190 Art 2 TEU. See also Kadi I and Kadi II (n 15).

191 See also Arts 21 and 23 TEU.

192 Art 21(2)(b) TEU.

193 Art 21(3) TEU.
} 
fields of international relations', ${ }^{194}$ 'build[ing] partnerships with third countries ... and promot[ing] multilateral solutions to common problems.' ${ }^{195}$ Under these provisions, the EU has human rights obligations, arising merely out of its competence and its capacity to realise them. We are aware of the fact that several related questions remain still to be explored and that additional research is needed to elucidate the exact content and extent of EU obligations, both negative and positive, in extraterritorial contexts. This contribution just sets the scene for a full debate on these questions.

194 Art 21(2) TEU. For a similar obligation to cooperate with third countries in the area of asylum and refugee protection, see Art 78(2)(g) TFEU.

195 Art 21(1), 2nd indent, TEU. 
